WellBeing International

WBI Studies Repository

1986

\title{
The Case for Hunting on National Wildlife Refuges
}

Harvey K. Nelson

U.S. Fish and Wildlife Service

Follow this and additional works at: https://www.wellbeingintlstudiesrepository.org/acwp_hmap

Part of the Animal Studies Commons, Other Anthropology Commons, and the Terrestrial and Aquatic Ecology Commons

\section{Recommended Citation}

Nelson, H.K. (1986). The case for hunting on national wildlife refuges. In M.W. Fox \& L.D. Mickley (Eds.), Advances in animal welfare science 1986/87 (pp. 283-294). Washington, DC: The Humane Society of the United States.

This material is brought to you for free and open access by WellBeing International. It has been accepted for inclusion by an authorized administrator of the WBI Studies Repository. For more information, please contact wbisr-info@wellbeingintl.org.

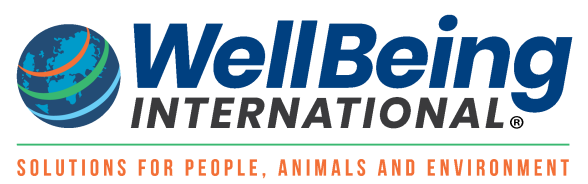




\title{
THE CASE FOR HUNTING ON NATIONAL WILDLIFE REFUGES ${ }^{1}$
}

\author{
Harvey K. Nelson ${ }^{2}$
}

\section{Introduction}

Public land management agencies are faced with greater challenges today than ever before in responding to the recreational needs of society. As Will Rogers so aptly stated, "Land, they make so little of it nowadays" (Steinhart 1986). The U.S. Fish and Wildlife Service (FWS) also must face these challenges in management of national wildlife refuges (NWRs). There is a growing demand by the American people to utilize and enjoy NWRs in a variety of ways. Managers are faced with the dilemma of determining how much and what kind of management and utilization of natural resources is appropriate without compromising the mandates and integrity of the 434 NWRs they administer (see figure 1). They must accept the fact that, in our complex society with sharply conflicting interests and philosophies, it is impossible to conduct management programs that will be acceptable to all the people all of the time. Hunting on NWRs is a prime example of this conflict.

In the last decade, recreational hunting has been challenged, largely on philosophical grounds. Some citizen's groups maintain that hunting is inhumane, irresponsible, and violates the rights of individual animals. Pro-hunting groups counter that hunting is a sound tool in wildlife management, that hunting license money has paid for much of the wildlife habitat that remains today, has provided the incentive to retain significant additional wildlife habitats, and that wild animals increase in value when they are used by man.

Since 1960 , a number of new refuges have been opened to hunting, and the trend has alarmed some groups. The Humane Society of the United States has charged that FWS is not complying strictly to Congressionally established mandates governing refuges. FWS takes the position that hunting on NWRs is an acceptable, traditional form of wildlife-oriented recreation that can also be used to manage wildlife populations.

This paper describes the historical, legal, social, and biological bases for the FWS position. 


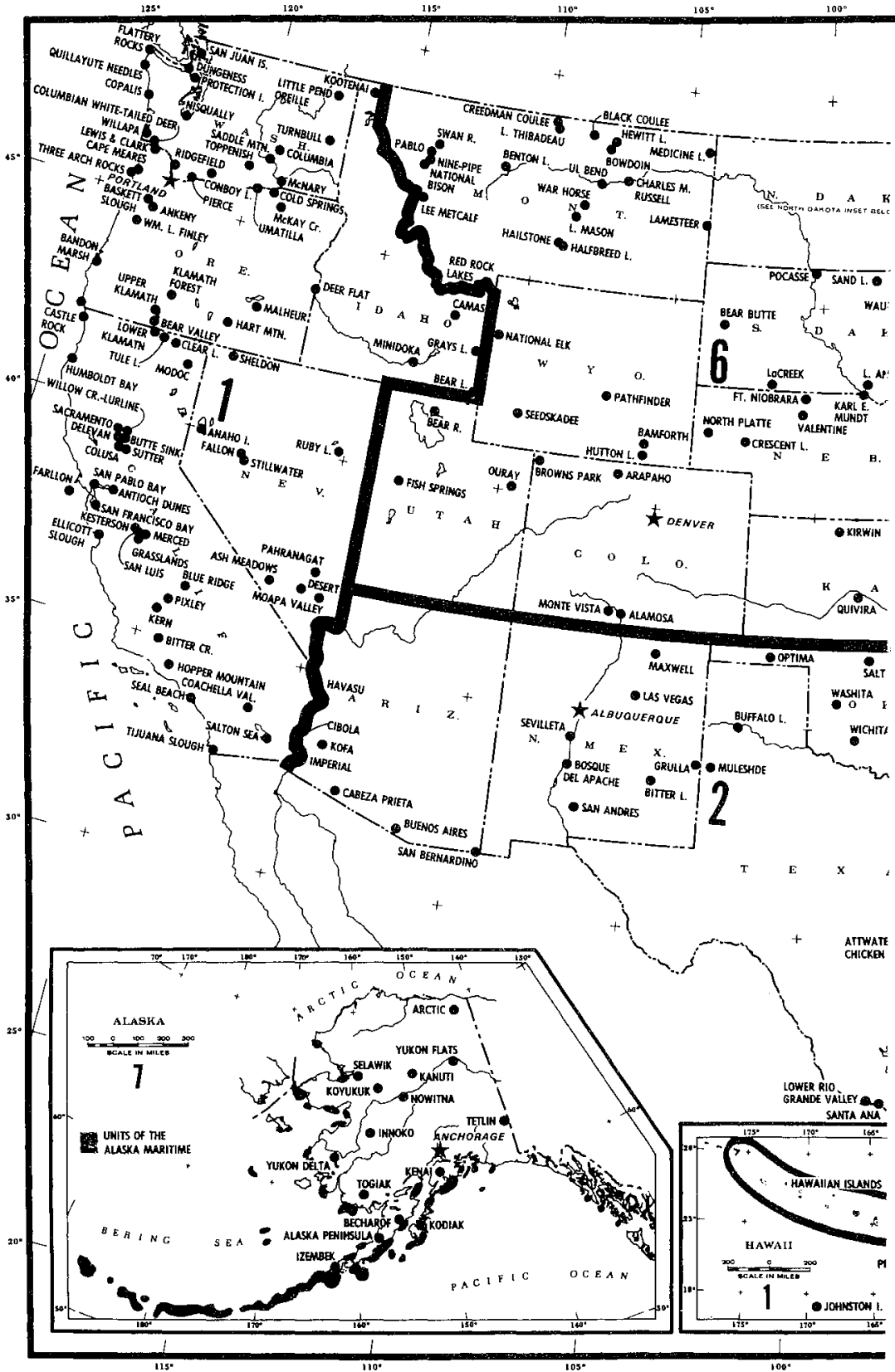




\section{Definitions}

\section{Types of Hunting}

Hunting can be viewed in historic, legal, or management perspectives.

Subsistence bunting is the taking of animals for food, shelter, or other personal uses essential to survival. For example, Peterle (1977) reported that the Eskimo hunters of Baffin Island acquire about $83 \%$ of their annual food by hunting marine mammals. Native people of the Yukon-Kuskokwim Delta in Alaska have relied on migratory birds for about $4 \%$ of their annual food supply, and this source is considered to be important seasonally (James Bartonek, Pacific Flyway Representative, Office of Migratory Bird Management, Portland, Oregon, personal communication).

Market bunting, the commercial harvest of wildlife, was at its peak during the latter part of the nineteenth century. Although market hunters usually made a portion of their living hunting wildlife, this term differs from subsistence in that most of the birds and animals taken are sold to someone else for profit. Some illegal market hunting and fishing still occurs today.

Sport bunting is generally construed to be pursuing and killing legal game animals with gun or bow for recreational purposes. Although most hunters consume the meat from the birds and animals they harvest, this is generally not the primary motivation.

\section{Hunted Populations}

Hunted populations are categorized as migratory birds, upland game, and big game. Management responsibility differs between categories as follows:

Migratory birds, species that migrate between breeding and wintering habitats are Federally protected by the Migratory Bird Treaty Act, as amended, by treaties with Great Britain (and Canada) (39 Stat. 1702), Mexico (50 Stat. 1311), Japan (concluded March 4, 1972), and Union of Soviet Socialist Republics (concluded November 19, 1976 [16 USC 715i]). In the United States, the FWS has primary responsibility for management of migratory species. Hunted populations include most waterfowl species, coots, sandhill cranes, bandtailed pigeons, whitewinged doves, mourning doves, woodcock, and snipe.

Upland game are resident, non-migratory species managed primarily by State wildlife agencies. Hunted populations include ring-necked pheasants, bobwhite quail, several species of grouse, gray partridge, wild turkeys, and numerous small mammals.

Big game management is also primarily a State responsibility. Hunted species include moose, elk, deer, caribou, wild sheep, pronghorns, mountain goats, and bears.

In any case, the FWS has the responsibility for any and all access or use of the NWRs regardless of the category of wildlife being hunted. 


\section{Biological Criteria}

Soundness. - A hunting program is considered biologically sound if a predetermined number of game animals can be removed from the population without adversely influencing the desired base population. Most wildlife species have the reproductive capacity to quickly fill a void in the population caused by the removal of individuals from natural mortality or harvest.

Population Control. - Where wild predators are absent, a common occurrence for big game species, normal productivity can lead to crowding, disease, malnutrition, and habitat destruction. There are numerous examples of these problems occurring with white-tailed deer. Similar problems are occurring today with certain populations of Canada geese that are increasing in numbers. Hunting is used as a management tool to reduce and hold the populations at levels that are within the carrying capacity of their environments. In the case of migratory birds, that carrying capacity includes an element of the tolerance of farmers to suffer crop depredation by those birds.

\section{Impact of Migratory Bird Hunting Stamp Act on Transition from Sanctuary to Management Area Concept}

Various publications (Reed and Drabelle 1984; Drabelle 1985) present accounts of the early establishment of the National Wildlife Refuge Systems (NWRS) and the evolution of hunting on those areas. The first NWRs were established as sanctuaries by President Theodore Roosevelt to protect colonial nesting birds heavily exploited by market hunters. In 1909, Congress authorized the first use of Federal funds to purchase land for wildlife. An area comprising 12,800 acres in Montana, now known as the National Bison Range, was acquired to protect habitat for the American bison, an animal that John Audubon predicted would become extinct without immediate protection. Thus, the first NWRs were established as inviolate sanctuaries against the onslaught of market hunting and habitat destruction. Reed and Drabelle (1984), reported:

Hunting was late to entrench itself in the National Wildlife Refuge System. Until 1949, it was permitted on only a few refuges, where it had been a traditional activity prior to the area's inclusion in the system and its continuation was a political necessity - no hunting, no refuge. This was the case with the first refuge opened to hunting, the Upper Mississippi River Wildlife and Fish Refuge, which Congress established in 1924 on condition that hunting be permitted there.

In 1934, passage of the Migratory Bird Hunting Stamp Act provided a new source of revenue for acquiring waterfowl refuges. Every waterfowl hunter the age of 16 or over was required to buy a duck stamp. When the FWS increased the price of the duck stamp from $\$ 1.00$ to $\$ 2.00$ in 1949 , it agreed to open up to $25 \%$ of the acreage on certain refuges to hunting. Wildlife 
management areas open to hunting increased to $40 \%$ in 1958 , when the duck stamp price was increased to $\$ 3.00$. Since 1960 , the increase in migratory bird hunting on NWRs correlates closely with the increase in duck stamp revenues as shown in figure 2 (Drabelle 1985; Superintendent of Documents 1981).

The National Wildlife Refuge System Administration Act of 1966, as amended, further expanded the Secretary of the Interior's authority for initiating hunting programs on NWRs. This Act also authorized the hunting of upland game and big game on refuge lands (Committee on Merchant Marine and Fisheries 1975).

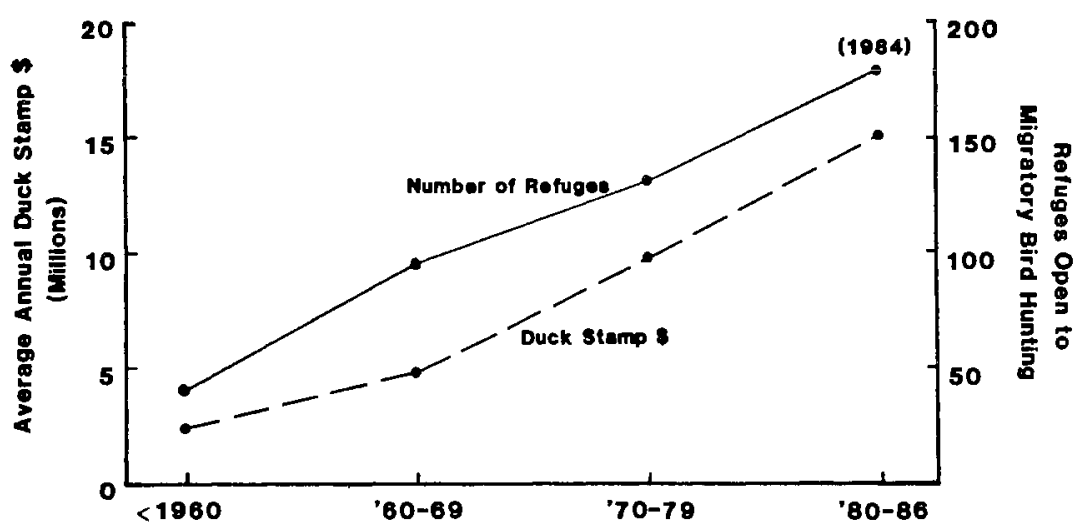

Figure 2. The number of refuges open to hunting for migratory birds has increased at the same rate as revenues from duck stamps.

Thus, hunting on NWRs is not a new phenomenon; it has been gradually increasing since 1935. In some instances, the provision of limited public hunting opportunity has been a condition of State approval for proposed Federal land acquisition.

\section{Refuge Acquisition and Funding}

The various refuges were created primarily by three means: (1) withdrawal from public lands via Executive Order, Proclamation, or Public Land Order; (2) purchase; or (3) legislative action. The majority of refuges created by the first mode, land withdrawals, could properly be opened to hunting under regulations established by the Secretary of the Interior through a series of executive orders and Presidential proclamations issued during the period 1934-40 (Presidential Proclamation 2287, June 6, 1938, Executive Order 2416, July 25, 1940).

The second mode of acquiring refuges was by purchase. Acquisition funds for land in NWRS come from two sources - the Migratory Bird Conservation Fund (MBCF) and the Land and Water Conservation Fund (LWCF). The MBCF depends primarily on duck stamp revenue and Congressional advances from 
the wetland loan fund. It is used to purchase production, migration, and wintering areas for migratory birds. A total of 186 refuges have been purchased with MBCF money and of these, 71 , or $38 \%$, are open to hunting. LWCF money comes from a variety of sources, such as off-shore oil and gas revenues, tax receipts from motor boat fuel, user fees, and sale of surplus government property, and has generally been used to purchase habitat for species other than migratory birds.

A third mode of early refuge acquisition was by direct legislative creation, and Congressional support of hunting is clear. Upper Mississippi River NWR and Bear River NWR are examples of early refuges where regulated hunting was allowed.

The provision for hunting on refuges - whether created by withdrawal, purchase, or legislation - thus reflects a long standing policy, enunciated by both Congress and the Executive Branch throughout the last 60 years. The refuges system have been created with an understanding that regulated public hunting is not, per se, barred and is often an important factor supporting the establishment of new refuges.

\section{Policies and Procedures Governing Refuge Hunting Programs}

The Secretary of the Interior is authorized by the National Wildlife Refuge System Administration Act of 1966, as amended, and the Refuge Recreation Act of 1962 to permit public recreational use, including hunting, on any refuge within the NWRS, providing that such recreational use will not interfere with the primary purposes for which the area was established and that funds are available for the development, operation, and maintenance of these permitted forms of recreation.

The dual needs for new recreational authorization and for control over possible recreational impairments of refuge purposes formed the background of the Refuge Recreation Act of 1962. Several concepts occurred throughout the history of this legisiation: (i) hunting is an accepted use of ren̂ges; (2) observation; and (3) concern that such uses might direct land purchased with duck stamp funds to benefit non-hunter recreationist who made little or no contribution to this fund.

\section{Procedural Requirements for Opening New Refuges to Hunting}

The Refuge Manual (U.S. Fish and Wildlife Service 1982) provides the specific management planning guidance for refuge managers who may be considering a hunting program. A specific hunting plan must be prepared.

During the planning process, a highly structured decision-making procedure is used to determine compatibility of hunting with refuge objectives. Conflicts between biological resources, management activities, and other public uses are resolved. Throughout the process, the public is encouraged to participate.

There are specific steps required before an NWR can be opened to hunting.

Compatibility. - First and foremost, refuge hunting programs must be compatible with the major purposes for which the refuge was established. The compatibility of hunting to refuge purposes has to be reviewed periodically. This is required by the NWRS Administration Act. 
Funding.-Funds must be available to develop, operate, and maintain a hunting program, as required by the Refuge Recreation Act of 1962. Hunting programs have, traditionally, been one of the least costly management tools available to refuge managers.

Environmental Impacts. - Any plan that will affect resources must be given environmental review. All hunting plans developed by the FWS have an Environmental Assessment, or, if necessary, an Environmental Impact Statement. These documents are prepared as required by the National Environmental Policy Act of 1969, as amended.

Endangered Species. - All hunting programs are reviewed to determine if they have impacts on threatened or endangered, sensitive species, or habitats. The refuge manager initiates appropriate consultation procedures in accordance with Section 7 of the Endangered Species Act.

Consultation and Coordination. - The affected state conservation agency is involved in the development or revision of any refuge hunting program and State approval in writing is required. Whenever possible, hunting regulations on refuges are the same as the State regulations. Refuge regulations may, on occasion, be more restrictive but may not be more liberal than State regulations. This approach fosters a spirit of State-Federal cooperation and minimizes the number of regulations required for refuge programs.

Refuges proposing new hunting programs or significant changes in existing programs must provide for public involvement in the decision-making process. This may range from informal consultation with interested individuals or groups to formal public meetings or workshops.

\section{Requirements of the Administrative Procedures Act}

When the planning effort for a proposed hunting program on a given refuge is completed and the necessary documentation has been compiled, reviewed, and approved, the proposed opening is published in the Federal Register. The Administrative Procedures Act requires a proposed rulemaking to be published, with a public comment period. Following the comment period, responses to all comments received are prepared and a final rulemaking incorporating the comments is published. If the decision is to proceed with the proposed opening, 30 days following the publication of the final rulemaking the refuge is listed in Title 50 Code of Federal Regulations ( 50 CFR) as open to hunting.

There are problems in dealing with refuge specific regulations on an annual basis. In 1960, the Fish and Wildlife Service implemented a provision for annual review of hunting plans and subsequent publication of annual hunting regulations for each refuge in the Federal Register. Because of the large number of refuges involved, this procedure became a costly administrative burden and the timely issuance of these regulations was jeopardized. The FWS recently modified this procedure and replaced the annual hunting regulations with refuge specific regulations codified in 50 CFR 32 . These regulations remain in effect on a given refuge until they are amended. Amendments must go through the steps discussed, concluding with publication in the Federal Register. 
The Humane Society of the United States filed a lawsuit in November, 1984, charging that the FWS had abandoned the annual review of hunting programs on refuges. While there has been no decision received, ${ }^{3}$ the FWS takes the position that it now requires closer review of hunting programs than previously. Existing compatibility and Section 7 determinations must now be reviewed annually and confirmation of existing determination or a new determination placed on file in the refuge office. Based on the author's recent experience, the codified refuge specific regulations which have been published for refuges in the FwS North Central Region are much improved in comparison to those published annually five years ago.

\section{Otber Guidelines for Conducting Refuge Hunts}

Hunting must be conducted to minimize conflicts with other refuge programs. Managers must consider the social impacts of hunting on other refuge visitors engaged in non-hunting activities. Often zoning the refuge ensures a quality experience for everyone.

Current demands for hunting in the vicinity of a refuge must be considered to determine if negative impacts on overall hunting opportunities in the surrounding area will occur as a result of the refuge hunting program. The potential for excessive demand must also be carefully evaluated to determine if hunter numbers need to be limited to maintain a quality hunting program and provide for participant safety.

Refuge hunting programs are planned, supervised, conducted, and evaluated to promote positive hunting values and hunter ethics. Refuge hunts are designed to provide participants with reasonable harvest opportunities, uncrowded conditions, and limited interference from, or dependence on, mechanized aspects of the sport. A responsible hunting program on refuges functions as an important management tool, while it also improves State and Federal cooperation and public enjoyment of Federal lands.

\section{Present Day Hunting on NWRs}

The NWRS presently includes 434 units encompassing approximately 88 million acres, of which 77 million are in Alaska (see figure 1). In addition, FWS administers more than 1.6 million acres of waterfowl production areas (WPAs) located in 152 counties in Iowa, Michigan, Minnesota, Montana, Nebraska, North Dakota, South Dakota, and Wisconsin.

Although the number of refuges open to hunting has increased, harvest of migratory birds and upland game has declined since the 1976 estimates were published in the Final EIS on Operation of the National Wildlife Refuge System. At the same time, refuge waterfowl production has increased by $120 \%$ (table 1).

In summary, during 1985, hunting was allowed on 236 refuges, or about $54 \%$ of the total NWRs. This includes all refuges in Alaska designated as being open to hunting by the Alaska National Interest Lands Conservation Act of 1980 (P.L. 96-487). In spite of increased numbers of refuges open to hunting, only about $1.6 \%$ of the annual U.S. waterfowl harvest was taken on the 179 refuges open to waterfowl hunting during 1984. 
Table 1. Comparison of hunting harvest and waterfowl production on national wildlife refuges between 1976 and 1983-84.

\begin{tabular}{lcc}
\hline Harvest & $\mathbf{1 9 7 6 \text { EIS }}$ & $\mathbf{1 9 8 3 - 8 4}$ Estimate \\
\hline migratory birds & 296,000 & 275,000 \\
upland game & 228,000 & 100,000 \\
big game & 10,200 & 16,000 \\
waterfowl production & 1.5 million & 3.3 million \\
\hline
\end{tabular}

\section{Conclusion}

Congress has for 60 years expressed a strong and unequivocal national interest in maintaining hunting opportunity on national wildlife refuges. There is a strong base of legislative and executive action, policy, program direction, and public interest to support regulated hunting on refuges.

The term "refuge" is often misunderstood to be synonymous with "sanctuary;" that is, a place where animals are protected from danger and distress. Thus, allowing hunting on refuges causes some confusion and concern among the public as to the intended purposes and management rationale for the NWRs. This is understandable, and clearly the question of what constitutes a "refuge" gets at the core of the issue.

Many wildlife species residing on refuges may occur in considerable numbers throughout thousands of acres of habitat. With the exception of some endangered species (such as the whooping crane), refuge managers, of necessity, must deal with animal populations, not individuals.

Congressional and legal mandates authorizing the establishment of individual refuges often prescribed that compatible forms of public use be permitted. Under these conditions, a more concise description of a "wildlife refuge" might be: "An area set aside for the protection and management of wildlife populations and their habitats and for the benefit of people." The FWS subscribes to the idea that it is possible to remove a given number of individuals of a population from a refuge by hunting, while still protecting, and, in some cases, improving the overall welfare of that population, as well as other species. Further, FWS believes that under given circumstances it is prudent management, and in the public interest, to not open certain refuges to hunting if a given species or group of species need complete protection.

The FWS will continue to defend its position on the appropriate role of hunting on NWRs where the required compatibility determinations have been met. At the same time, the agency recognizes the important role of citizen's groups that hold differing viewpoints. Constructive criticism of government programs by citizens ensures that agencies comply with their legal and moral responsibilities to manage resources for the best interests of the public at large.

The FWS will strive to improve the quality of refuge hunting programs in the future. Former FWS Director Greenwalt (1978) summarized this policy quite well: 
The quality of the hunting on refuges will increase as the Fish and Wildlife Service efforts to this end are increased. More hunts will be controlled; that is, limits will be imposed upon the total numbers of hunters present at any one time on certain refuges... and, consequently, the possible conflicts between hunters and those refuge visitors who prefer not to hunt will be reduced.

Peterle (1977) predicted that the proportion of the total human population participating in hunting will continue to decrease in the future. However, the demand to hunt on refuges may continue to increase because of fewer opportunities to hunt on private lands. Concurrently, the demand for non-hunting uses of NWRs is expected to continue to increase. In the future, managers must place greater emphasis on the social aspects of refuge hunting in terms of its relationship to, and perception by, other users of refuge resources.

\section{Acknowledgement}

Special thanks to Robert Drieslein, Jan Eldridge, Calvin Gale, James Gillett, and Robert Oetting, FWS staff members who provided assistance and editorial review of this manuscript.

\section{Endnotes}

${ }^{1}$ Paper presented at the national conference, "Animals and Humans: Ethical Perspectives," Moorhead State University, Moorhead, MN, April 21-23, 1986.

${ }^{\mathbf{2}}$ Regional Director, U.S. Fish and Wildlife Service, Federal Building, Fort Snelling, Twin Cities, MN 55111.

${ }^{3}$ On July 25, 1986, the United States District Court for the District of Columbia ruled that The Humane Society of the United States lacked standing to bring the case in behalf of its members. The Court ordered that summary judgment shall be entered in favor of the defendants on all of the Humane Society's claims, but excepted an individuai piaintiff's claim based on defendant's alleged failure to prepare environmental analyses for hunt openings occurring since 1980. The Court allowed further proceedings on that single issue.

\section{References}

Carey, J. 1986. Changing face of America, 50 years of land use. In: Strom, J. ed. National Wildlife. Washington, DC: National Wildlife Federation. pp. 8-27.

Committee on Merchant Marine and Fisheries. 1975. A Compilation of Federal Laws Relating to Conservation and Development of our Nation's Fish and Wildlife Resources, Environmental Quality, and Oceanography. Washington, DC: U.S. Govt. Print. Off.

Drabelle, D. 1985. The National Wildlife Refuge System. In: Di Silvestro, RL. ed. Audubon Wildlife Report - 1985. Washington, DC: National Audubon Society.

General Services Administration. 1984. Code of Federal Regulations, Title 50. Washington, DC: U.S. Govt. Print. Off.

Greenwait, L. 1978. The National Wildlife Refuge System. In: Brokaw, H. ed. Wildlife in America. Washington, DC: U.S. Govt. Print. Off.

Peterle, T. 1977. Hunters, hunting, anti-hunting. Wildlife Soc. Bull. 5(4): 151-61.

Reed, N and Drabelle, D. 1984. The United States Fish and Wildlife Service. Boulder, CO: Westview Press, Inc.

Superintendent of Documents. 1981. Duck stamp data. Washington, DC: U.S. Govt. Print. Off. 
United States Code Annotated. 1982. Title 16. Conservation 461 to 760. St. Paul, MN: West Publishing Co.

U.S. Department of the Interior. 1976. Final Environmental Statement: Operation of the National Wildlife Refuge System. Washington, DC: U.S. Govt. Print. Off.

- 1979. Final Recommendations on the Management of the National Wildlife Refuge System. Washington, DC: U.S. Govt. Print. Off.

U.S. Fish and Wildlife Service. 1982. Refuge Manual. Washington, DC: U.S. Govt. Print. Off. 